\title{
STUDIES OF THE BURIAL MOUND PANAGIA 2 ON THE TAMAN PENINSULA
}

\author{
Andrey A. Goroshnikov \\ Kubanarkheologiya Ltd., Krasnodar, Russian Federation
}

\begin{abstract}
Two barrows of the burial mound Panagia 2 were investigated in the neighborhood of Volna village on the Taman peninsula in the Krasnodar region. The barrows were erected in the Middle Bronze Age, with the secondary graves of the Late Bronze Age and the Middle Ages. Two graves belong to the early times of so-called 'catacomb culture', four - to the Late Bronze Age and one - to the Middle Ages. Barrow two was overlapped with a layer dating back to the Late Bronze Age settlement of Panagia 1, located near the burial mound. The pots of very simple shape with straight walls extending to the mouth were found in the burials. In the settlement' layers pottery of the late Bronze Age were collected. There are vessels with convex rollers and loop-handles.

The studied monument - Panagia 2 burial mound - gave a number of complexes, both funeral, and settlement, supplementing and expanding our ideas of material culture of the population of the Taman Peninsula during different eras, mainly, during the Bronze Age, which monuments on Taman were poorly studied until recently.

The present publication is aimed at introduction of new sources for studying the ancient history of Northwest Pontic Region to modern archaeology.

Key words: Taman Peninsula, barrow, Middle Bronze Age, Late Bronze Age, catacomb Culture, burial, settlement.

Citation. Goroshnikov A.A., 2018. Studies of the Burial Mound Panagia 2 on the Taman Peninsula. The Lower Volga Archaeological Bulletin, vol. 17, no. 2, pp. 135-152. (in Russian). DOI: https://doi.org/10.15688/ nav.jvolsu.2018.2.11
\end{abstract}

УДК 902.2

ББК $63.4(2)$
Дата поступления статьи: 10.10 .2018 Дата принятия статьи: 16.11.2018

\section{ИССЛЕДОВАНИЯ КУРГАННОГО МОГИЛЬНИКА ПАНАГИЯ 2 НА ТАМАНСКОМ ПОЛУОСТРОВЕ}

\author{
Андрей Алексеевич Горошников \\ ООО «Кубаньархеология», г. Краснодар, Российская Федерация
}

\begin{abstract}
Аннотация. В сентябре 2017 г. археологический отряд ООО «Кубаньархеология» проводил исследования курганного могильника Панагия 2 в Темрюкском районе Краснодарского края. Раскопаны два кургана в окрестностях пос. Волна Темрюкского района Краснодарского края. В них находились погребения эпохи средней и поздней бронзы, а также средневековья. Два погребения относятся к раннему этапу катакомбной культуры, четыре - к эпохе поздней бронзы, одно безынвентарное - к эпохе средневековья. Помимо погребений, в кургане 2 были обнаружены комплексы поселенческого типа, относящиеся к посе$\infty$ лению эпохи поздней бронзы Панагия 1. Собрана коллекция фрагментов сосудов эпохи поздней бронзы, 훙 среди которых имеются сосуды с налепными валиками и ручками-«ушками». В погребениях эпохи по\& здней бронзы отмечены слабопрофилированные горшки, а также сосуд баночного типа. Исследованный ґ памятник - курганная группа Панагия 2 дал целый ряд комплексов - как погребальных, так и поселенчес\%ै ких, дополняющих и расширяющих наши представления о материальной культуре населения Таманского полуострова в разные эпохи, преимущественно в эпоху бронзы, памятники которой на Тамани до послед днего времени были слабо изучены.

Настоящая публикация ставит своей целью введение в научный оборот новых источников для изучения древней истории Северо-Западного Причерноморья.
\end{abstract}


Ключевые слова: Таманский полуостров, курган, эпоха средней бронзы, эпоха поздней бронзы, катакомбная культура, погребение, поселение.

Цитирование. Горошников А. А., 2018. Исследования курганного могильника Панагия 2 на Таманском полуострове // Нижневолжский археологический вестник. Т. 17, № 2. С. 135-152. DOI: https://doi.org/10.15688/ nav.jvolsu.2018.2.11

В сентябре 2017 г. археологический отряд ООО «Кубаньархеология» проводил исследования курганного могильника Панагия 2 в Темрюкском районе Краснодарского края.

Настоящая публикация ставит своей целью введение в научный оборот новых источников для изучения древней истории СевероЗападного Причерноморья.

Курганный могильник, состоящий из 2 насыпей, располагался в 6,53 км к северо-западу от школы в п. Волна и в 8,37 км к югозападу от памятника освободителям Тамани, павшим в Великой Отечественной войне, расположенного в ст. Тамань (рис. 1).

Памятник находился на возвышенности, расположенной в центре юго-западной части Таманского полуострова, в урочище Холодная Долина. Насыпи курганов и прикурганная территория занимали участок поля с заброшенным виноградником. Все насыпи были значительно деформированы распашкой. Курганы вытянуты цепочкой по линии С--ЮВ. К востоку от памятника проходила ЛЭП, к югу грунтовая дорога (рис. 1,1).

Раскопки осуществлялись с использованием землеройной техники, могильник был исследован полностью. При описании погребений в тексте все глубины указываются от центра насыпи.

Курган 1 (рис. 1,1). Крайний юго-восточный в могильнике, был расположен на расстоянии 210 м к северу от грунтовой дороги. Насыпь кургана к началу раскопок имела высоту 0,2 м, диаметр 20 м.

Для фиксации стратиграфии насыпи курган раскапывался с оставлением одной контрольной бровки по линии С-Ю. Западный профиль бровки зачищался и зачерчивался (рис. 2,2).

Верхний слой составлял дерн мощностью до 0,1 м, ниже - слой плотного гумусированного суглинка серо-коричневого цвета мощностью $0,25-0,55$ м, подстилающийся плотной супесью серо-коричневого цвета мощностью $0,25-0,5$ м. Ниже серо-коричневой супеси за- легал слой рыхлой супеси желто-коричневого цвета толщиной $0,3-0,75$ м, перекрывающий рыхлую супесь желто-белого цвета с включением железняка (материк).

Из-за плантажной распашки определить границы насыпи и погребенной почвы кургана, проследить порядок сооружения насыпи в стратиграфическом разрезе не представляется возможным. Не исключено, что для захоронения использовалось естественное возвышение на террасе.

Всего в кургане зафиксировано три погребения и один объект.

Погребение 1. Обнаружено в 3 м к 3 от центра насыпи (рис. 2). Могильная яма, сооруженная в слое материковой супеси и заполненная таким же грунтом, не прослежена. На глубине 1,44-1,5 м зачищены отдельные фрагменты трубчатых костей человека, а также пятна костного тлена.

Судя по сохранившимся останкам, погребенный лежал в скорченном положении на левом боку черепом к ЮВ (рис. 3,2 ). Угол между сохранившимися костями ног в коленном суставе составляет около $60^{\circ}$. В 0,30 м к СВ от трубчатых костей на глубине 1,45 м расчищены участки костного тлена, вероятно, от тазовых костей и костей позвоночника. Пол и возраст погребенного не определяются.

В ногах погребенного стоял лепной горшок. Венчик скруглен, слабо выделенный, слегка отогнут наружу, плавно переходит в округлое плечо, затем тулово слегка сужается к дну. Дно плоское. Тесто рыхлое, с примесью шамота. Диаметр дна - 10 см, венчика 11 см, высота горшка - 10,2 см, толщина стенки $-0,6$ см.

Погребение 2. Обнаружено на расстоянии 9 м к Ю3 от центра насыпи (рис. 2). Могильная яма, сооруженная в слое материковой супеси и заполненная таким же грунтом, не прослежена.

На глубине 1,35 м от центра насыпи зачищены два мелких фрагмента черепа че- 
ловека плохой сохранности. В 0,3 м к 3 от фрагментов черепа на глубине 1,25-1,37 м была найдена нижняя часть лепного горшка (рис. 3,5). Горшок имеет плоское дно, верхняя часть горшка выше плеча утрачена (рис. 3,6). Цвет поверхности от кирпичного до темно-серого, в изломе трехслойный. Тесто рыхлое, с примесью шамота. Диаметр дна $-8,5$ см, максимальный диаметр тулова $-12,5$ см, толщина стенки $-0,7$ см, сохранившаяся высота - 9 см.

Погребение 3. Обнаружено на расстоянии 8 м к В от центра (рис. 2). Могильная яма, сооруженная в слое материковой супеси и заполненная таким же грунтом, не прослежена.

На глубине 1,32 м от центра насыпи зачищены три фрагмента костей человека плохой сохранности, сильно заизвесткованные (рис. 3,7). В 0,08 м к В от фрагментов костей на глубине 1,26-1,38 м стоял лепной горшок баночной формы (рис. 3,8 ). Сосуд имеет плоское дно, стенки плавно расширяются, максимальный диаметр на уровне плеча. Плечо плавно переходит в слабо выделенное горло. Край венчика скруглен. Цвет поверхности варьирует от черного до розовато-кирпичного. Черепок в изломе черный. Тесто с примесью шамота. Диаметр дна - 10,5 см, венчика - 16 см, максимальный диаметр тулова 17,8 см, высота сосуда - 12,5 см.

Объект 1. Обнаружен в центре насыпи, на глубине от 1,2 до 1,34 м (рис. 2). Представляет собой аморфное в плане скопление плит и обломков известняка и песчаника, расчищенное на участке размерами $0,75 \times 1,05$ м (рис. 3,1 ).

В заполнении между камнями фиксировались фрагменты керамики и костей животных. Было обнаружено 10 фрагментов стенок лепных сосудов и фрагмент бортика лепной миски (рис. 3,3). Край венчика скруглен. Цвет поверхности от кирпичного до серого, в изломе черный. Тесто с примесью шамота. Диаметр - 14 см, толщина стенки - 0,9 см.

Курган 2 (рис. 4,1). Находился в 63 м к С3 от кургана 1. Насыпь высотой 0,3 м, диаметр - 30 м.

Раскопки производились с оставлением контрольных бровок по линии С-Ю и 3-В, фасы которых зачищались и зачерчивались (рис. 4,1 ). Верх стратиграфического разреза составлял дерновый слой мощностью до 0,15 м, ниже - слой плотного гумусированного суглинка серо-коричневого цвета мощностью $0,2-0,4$ м, подстилающийся плотной супесью серо-коричневого цвета мощностью $0,4-0,65$ м. Ниже залегал слой рыхлой супеси желто-коричневого цвета мощностью 0,40,8 м, перекрывающий рыхлую супесь желто-белого цвета с включением железняка (материк).

В профиле насыпи, как и в горизонтальных ее срезах, никаких перекопов и прослоек не фиксировалось, что позволяет предполагать, что, как и в кургане 1, погребения были впущены в естественную возвышенность.

Выкиды из могильных ям на ее поверхности, даже если они и были перекрыты незначительной досыпкой, могли быть уничтожены в результате распашки.

Всего в кургане обнаружено пять погребений и восемь объектов, представляющих собой скопления камней, фрагментов керамики и костей животных, а также развал лепного сосуда и остатки каменного основания фундамента постройки (?).

Находки в насыпи. На расстоянии 7,45 м к Ю3 от центра насыпи на глубине 0,55 м найден фрагмент плеча с частью горла и венчика лепного горшка (рис. $4,1,2)$. На внешней поверхности ниже плечика расположены три параллельных вертикальных валика. Горло воронковидное, край венчика скруглен. Цвет поверхности серый, в изломе темно-серый. Тесто с примесью мелких белых частиц и шамота. Диаметр - 33 см, толщина стенки $-0,6-0,8$ см.

Керамика относится к эпохе поздней бронзы.

Погребение 1. Обнаружено на расстоянии 12 м к Ю3 от центра (рис. 4,1). Могильная яма, сооруженная в слое супеси желтокоричневого цвета и заполненная таким же грунтом, не прослежена.

На глубине 1,06 м зачищены два фрагмента костей черепа человека, сильно заизвесткованных (рис. 5,1).

В 0,08 м к северу от фрагментов черепа на глубине 1,02-1,09 м был расчищен лепной 
горшок (рис. 5,2). Горшок имеет плоское дно, слабо выделенное горло и скругленный край венчика. Цвет поверхности серый, в изломе черный. В тесте примесь мелкого песка и мелких белых частиц. Диаметр дна - 7,3 см, венчика - 11,5 см, высота сосуда $-9,3$ см.

Погребение 2. Обнаружено в 5,6 м к Ю3 от центра насыпи, зачищено на глубине от 1,09 до 1,22 м (рис. 4,1). Могильная яма, сооруженная в слое супеси желто-коричневого цвета и заполненная таким же грунтом, не прослежена.

Судя по сохранившимся останкам, погребенный (мужчина старше 55 лет) ${ }^{1}$ лежал в скорченном положении на правом боку черепом к Ю3, лицевым отделом на ЮВ (рис. 5,3). Плечевая кость левой руки параллельна позвоночнику. Угол, под которым ноги погребенного были согнуты в коленных суставах, по сохранившимся фрагментам определить невозможно.

Инвентарь отсутствует.

Погребение 3. Обнаружено на расстоянии 12,3 м к Ю3 от центра насыпи (рис. 4,1). Могильная яма, сооруженная в слое супеси желто-коричневого цвета и заполненная таким же грунтом, не прослежена.

На глубине 1,20-1,25 м зачищена нижняя часть скелета человека (рис. 5,4). Кости очень плохой сохранности. Погребенный мужчина 45-55 лет был уложен в положении «вытянуто на спине» черепом на 3.

Прослежены фрагменты костей таза, обеих бедренных, малой и большой берцовых костей правой и большой берцовой кости левой ноги.

Судя по расположению фрагментов, берцовые кости правой ноги находились в анатомическом порядке, левая смещена на 0,2 м к СВ землероями.

Погребение безынвентарное.

Погребение 4. Обнаружено на расстоянии 12,4 м к Ю3 от центра (рис. 4,1). Прослежено по пятну рыхлой супеси желто-коричневого цвета. С юга к пятну примыкает известняковая плита, установленная вертикально на ребре, размерами $0,3 \times 0,7$ м и толщиной 0,1 м. Ее положение в сопряжении с контуром могильной ямы позволяет предположить, что она является закладом входа в камеру катакомбного захоронения. Входной колодец катакомбы, заполненный грунтом, аналогичным грунту насыпи кургана, не прослеживался.

Не исключено, что каменная наброска, зафиксированная как объект 8 в 0,35 м выше уровня зачистки пятна, перекрывала заполнение входного колодца, и при обрушении свода камера сместилась к СВ, и просела в ее заполнение (рис. 4,1).

Погребальная камера овальной формы, длинной осью вытянута по линии СС3ЮЮВ (рис. 5,5). Глубина ее 0,09-0,19 м в северной и северо-западной частях и $0,09-$ 0,22 м в юго-восточной и южной от уровня зачистки пятна.

Стенки в северо-западной части ровные, расширяются к дну, образуя неглубокий подбой, в остальных - сужаются к дну. Переход от стенок к дну подрезан и скруглен. Дно ровное.

Заполнение однородное, состоит из рыхлой супеси желто-коричневого цвета с включением мешаной материковой желто-белой супеси.

Погребенный мужчина 45-55 лет находился в центре камеры в скорченном положении на правом боку черепом к 3 (рис. 5,5 ). После разложения мягких тканей туловище завалилось влево, и лежит в положении «на спине». Череп на правой височной кости лицевым отделом к Ю, к входу в камеру.

Анатомический порядок костей нарушен в результате обвала свода камеры - плечевые кости левой руки и ребра левой стороны грудины смещены к $\mathrm{C}$ на $0,07-0,4$ м.

In situ сохранились кости правой руки, согнутые в локтевом суставе, $\mathrm{P}=124^{\circ}$, кисть в области таза. Лучевая кость предплечья правой руки была смещена, и лежит практически перпендикулярно позвоночному столбу.

Сохранившиеся кости правой ноги согнуты в тазобедренном суставе под углом около $150^{\circ}$, угол в коленном суставе составляет $47^{\circ}$. Бедренная кость левой ноги согнута в тазобедренном суставе под углом $104^{\circ}$, кости левой голени смещены к северо-восточной стенке камеры.

Стопы были сведены вместе, однако, грызунами были смещены к СВ на $0,25-0,3$ м кости левой стопы, а также большая берцовая кость левой ноги. 
Под ней на дне прослежено пятно красной краски овальной формы размерами около $0,15 \times 0,25 \mathrm{M}$.

Аналогичное аморфное пятно краски размерами $0,06-0,13 \times 0,15$ м было расчищено на расстоянии 0,30 м к Ю от первого пятна у восточной стенки камеры.

Инвентарь:

1. В южной части камеры, на расстоянии 0,25 м от входа, лежала лопатка, а в юговосточном углу - фрагмент челюсти мелкого рогатого скота.

Погребение 5. Обнаружено в центральной части насыпи, на расстоянии 1,65 м к Ю3 от центра (рис. 4,1). Совершено в катакомбе (рис. 6)

Входной колодец, сооруженный в слое материковой супеси и располагавшийся в юговосточной части катакомбы, прослежен не полностью - на глубине 1,62-1,68 м от центра насыпи было расчищено углубление подквадратной формы, углами ориентированное по сторонам света, сделанное в дне колодца перед входом в камеру. Размеры его $0,65 \times 0,7$ м, глубина - от 0,09 до 0,16 м от уровня зачистки. Стенки ровные, отвесные, сужаются к дну. Переход от стенок к дну подрезан и скруглен. Дно ровное.

В центральной части углубления расчищены камни заклада - три крупные плиты известняка, установленные вертикально на ребpe. Размеры камней $0,25 \times 0,45-0,3 \times 0,4$ м, толщина - 0,1-0,15 м.

Вход в камеру оформлен ступенькой глубиной до 0,3 м от уровня дна углубления.

Погребальная камера прослежена по пятну супеси желто-коричневого цвета, зачищена на глубине 1,62-1,71 м. Камера подпрямоугольной формы со скругленными углами, вытянута длинной осью по линии СВ-Ю3.

Размеры камеры 2,5 × 1,6 м, глубина $0,35-0,45$ м от уровня зачистки пятна. Стенки ровные, отвесные, слабо расширяются к дну в северо-восточной и юго-западной частях, в остальных - сужаются. Переход от стенок к дну подрезан и скруглен. Дно ровное, понижается к центру на $0,03-0,06$ м.

Заполнение камеры однородное, состоит из рыхлой супеси желто-коричневого цвета с включением материковой супеси желтобелого цвета.
Погребенный мужчина 25-35 лет был положен в центре камеры, ближе к юго-западной стенке в скорченном положении на правом боку черепом к ЮЗ. После разложения мягких тканей туловище завалилось влево, и лежит в положении «на спине». Череп на правой височной кости лицевым отделом к ЮВ, к входу в камеру.

Плечевая кость правой руки и фрагмент лучевой кости вытянуты вдоль туловища параллельно позвоночному столбу.

Плечевая кость левой руки отведена в сторону, с плечевым поясом $\mathrm{P}=40^{\circ}$, рука была согнута в локтевом суставе, $\mathrm{P}=80^{\circ}$, кисть в области низа грудины.

Сохранившиеся кости правой ноги согнуты в тазобедренном суставе под углом около $132^{\circ}$, угол в коленном суставе составляет $40^{\circ}$. Бедренная кость левой ноги согнута в тазобедренном суставе под углом $106^{\circ}$, угол в коленном суставе составляет $30^{\circ}$. Стопы сведены вместе.

Вплотную к погребенному с ЮВ примыкают лежащие вперемешку кости расчлененного костяка второго погребенного - мужчины 25-35 лет.

Оба погребенных были уложены на подстилку, от которой сохранился органический тлен коричневого цвета (плетеная циновка?).

Прослежена посыпка красной краской в области костей левой руки, тазобедренного сустава, костей голени и стоп погребенного 1 ; в области черепа погребенного 2 - пятно краски овальной формы размерами $0,1 \times 0,2$ м.

На расстоянии 0,5 м от погребенных в северо-восточной части камеры на глубине 2,08 м обнаружена ключица, вероятно, принадлежащая костяку № 2 и перемещенная грызунами.

Объект 1. Расположен на расстоянии 14,3 м к ЮВ от центра насыпи, зачищен на глубине от 1,02 до 1,19 м (рис. 4,1). Представляет собой скопление мелких обломков известняка и песчаника, фрагментов лепной керамики, обожженной обмазки и костей животных, расчищенное на участке размерами $0,55 \times 1,0$ м (рис. 9,1).

Объект 2. Расположен на расстоянии 2 м к В от центра насыпи (рис. 4,1). Зачищен на глубине от 0,37 до 0,71 м в западной части и на глубине от 0,45 до 0,85 м - в восточной. 
Представляет собой остатки каменного основания фундамента постройки, расчищенные на участке размерами $11,5 \times 18,5$ м (рис. 7). Вероятно, изначально постройка имела овальную форму и была ориентирована в направлении СВ-Ю3. Сохранившийся участок в плане дуговидной формы состоит из крупных плит, глыб, обломков известняка и песчаника, между которыми фиксируются мелкие камни забутовки. Выделяется два ряда камней - внешний и внутренний, между которыми промежуток в 1-2 м. Ширина внешнего ряда составляет $1,25-1,5$ м, внутреннего - 1,5-2,4 м. Нельзя с уверенностью сказать, было ли пространство между рядами изначально или же впоследствии сплошная кладка была разобрана, так как в западной и юговосточной частях объекта расчищены отдельные камни, расположенные между внешним и внутренним рядами.

Камни залегают на одном горизонте в слое плотной супеси серо-коричневого цвета высотой в один ряд.

В заполнении между камнями фиксируются фрагменты керамики и обожженной обмазки, керамического шлака, а также кости животных.

В юго-восточной части на глубине $0,63-0,78$ м на участке размерами $1,1 \times 3,1$ м был расчищен развал крупного лепного сосуда (рис. 7, 8,1). Горло воронковидное, край венчика скруглен. Переход горла в плечо опоясан налепным заостренным валиком. На краю слома одного фрагмента ребро резко уходит вниз. Цвет поверхности от серого до кирпичного, в изломе темно-серый. Тесто с примесью мелких белых частиц. Диаметр венчика - 34 см, толщина стенки $0,9-1,2$ см.

Помимо развала сосуда, также были найдены профильные фрагменты керамических сосудов и фрагмент керамического пряслица (рис. 8,2-14). Цвет поверхности керамики варьирует от серого до кирпичного, в изломе темно-серого цвета. Тесто с примесью мелких белых частиц, шамота, органики, песка и толченой раковины.

Вероятно, ориентировка постройки по линии СВ-Ю3 позволяла укрыться от северо-восточных ветров, характерных для Таманского полуострова в зимнее время.
Объект 3. Расположен на расстоянии 9,5 м к Ю3 от центра насыпи, зачищен на глубине от 0,74 до 0,88 м (рис. 4,1 ). Представляет собой две крупные плиты известняка, расчищенные на участке размерами 2,3 × 1,25 м (рис. 9,2). Размеры плит - 0,75 × 1,25 (западная) и $0,55 \times 0,9$ м (восточная), толщина 0,15 м, восточная плита расколота.

В заполнении между камнями фиксировались фрагменты керамики и кости животных.

Объект 4. Расположен на расстоянии 15,8 м к Ю3 от центра насыпи, зачищен на глубине от 1,15 до 1,32 м (рис. 4,1 ). Представляет собой скопление плит, глыб и мелких обломков известняка и песчаника, вытянутое по линии $\mathrm{C}-\mathrm{Ю}$, расчищенное на участке размерами $1,15 \times 1,55$ м (рис. 9,3).

В заполнении между камнями фиксировались фрагменты керамики и кости животных. Найдены фрагмент ручки лепного сосуда, фрагмент бронзового стержня и две раковины моллюсков Cerastoderma glaucum с отверстием для подвешивания в вершинной части (рис. 9,4,5).

Ручка в сечении овальная, цвет поверхности кирпичный, на изломе серый. Тесто с примесью шамота. Размеры - 3,2 × 1,3 см.

Бронзовый стержень в сечении прямоугольный, сечение $0,4 \times 0,3 \mathrm{~cm}$, сохранившаяся длина $-5,5$ см.

Объект 5. Расположен на расстоянии 12 м к Ю3 от центра насыпи, зачищен на глубине от 1,18 до 1,24 м (рис. 4,1). Представляет собой бессистемное скопление из обломка известняка, пяти фрагментов стенок лепных сосудов и одиннадцати фрагментов костей животных, расчищенное на участке размерами $0,3 \times 0,3$ м (рис. 9,6).

Объект 6. Расположен на расстоянии 10,7 м к Ю3 от центра насыпи, зачищен на глубине от 1,2 до 1,3 м (рис. 4,1 ). Представляет собой скопление мелких обломков известняка и песчаника, фрагментов лепной керамики, обожженной обмазки и костей животных, расчищенное на участке размерами $0,7 \times 1,05$ м (рис. 9,7).

Объект 7. Расположен на расстоянии 10,2 м к Ю3 от центра насыпи, зачищен на глубине от 1,31 до 1,48 м (рис. 4,1). Залегает на $0,1-0,18$ м ниже объекта 6 и, вероятно, со- 
ставляет с ним единый комплекс. Объект представляет собой скопление мелких обломков известняка, крупной плиты, костей животных и развала лепного сосуда, расчищенное на участке размерами $1 \times 1,7$ м (рис. 9,8).

Горло сосуда слабо выделено, венчик скруглен, ниже плеча сохранилась часть налепного валика (рис. 9,9). Цвет поверхности от серого до коричневого, в изломе темно-серый. Тесто с примесью толченых раковин и шамота. Диаметр сосуда - 26 см, толщина стенки - 1,2 см.

Объект 8. Расположен на расстоянии 13 м к Ю3 от центра насыпи, зачищен на глубине от 1,2 до 1,65 м (рис. 4,1).

Представляет собой скопление обломков и глыб известняка и песчаника, а также большой плиты известняка, расчищенное на участке размерами $1,25 \times 1,45$ м (рис. 9,10). В заполнении между камнями обнаружены фрагменты лепной керамики и кости животных.

В южной части объекта расчищена крупная плита, установленная вертикально. Верхний край ее находится на $0,17-0,25$ м выше основной группы камней, нижний - на $0,2-0,3$ м ниже. После снятия основной группы камней и зачистки пространства под ними, было зачищено пятно погребения 4.

$$
* * *
$$

Форма и типологические особенности керамического инвентаря, обнаруженного в погребениях 1-3 кургана 1, находят аналогии среди сосудов из погребальных комплексов, обнаруженных в слое поселения эпохи поздней бронзы Панагия 1 , исследуемого в настоящее время [Раев, Горошников, 2018, с. 135], вследствие чего эти погребения можно с уверенностью отнести ко времени существования поселения.

Керамика, обнаруженная в объекте, расчищенном в центральной части насыпи, также относится к эпохе поздней бронзы. Вероятно, объект представлял собой остатки тризны над погребениями.

В кургане 2 были обнаружены 5 погребений различных эпох - от средней бронзы до средневековья.
В эпоху средней бронзы совершены погребения $2,4,5$. По деталям погребального ритуала погребения 4, 5 могут быть отнесены к раннему этапу катакомбной культуры.

Лепной сосуд, обнаруженный в погребении 1 , аналогичен сосудам из слоя поселения Панагия 1, что позволяет датировать погребение эпохой поздней бронзы.

Безынвентарное погребение 3, судя по положению умершего, скорее всего, относится к эпохе средневековья.

Принимая во внимание расположение погребений на общем плане кургана 2, можно определенно утверждать, что первоначальная насыпь была возведена над погребениями эпохи средней бронзы 2,4 и 5 (рис. 4,1 ).

В период существования поселения в эпоху поздней бронзы, насыпь, вероятно, могла использоваться как жилой холм, о чем говорят обнаруженные объекты 1-4.

Объекты 5-7 могут быть как поселенческими, так и представлять собой остатки тризн.

Объект 8 может быть как поселенческим, так и связанным с конструкцией катакомбного захоронения 4.

В насыпи и заполнении объектов кургана 2 были обнаружены находки, относящиеся к культурному слою поселения эпохи поздней бронзы Панагия 1. Они представлены фрагментами стенок лепных сосудов, обожженной обмазки, керамического шлака, а также профильными частями лепных сосудов, фрагментом конусовидного керамического пряслица. Среди керамического материала преобладают профилированные горшки. Обнаружен также фрагмент миски открытого типа с округленными стенками, фрагменты корчаг и фрагмент крышки сосуда.

Среди профильных частей горшков и корчаг бо́льшую часть составляют верхние части сосудов - шейки с частью венчика.

Около четверти сосудов, представленных в коллекции, орнаментированы. В орнаментации преобладает рельефный орнамент - налепы, горизонтальные валики, как гладкие, так и дополнительно декорированные вдавлениями, также ручками-ушками. Горизонтальные замкнутые валики чаще опоясывают основание шейки, либо верхней ча- 
сти плеча, но встречаются и разомкнутые, с опущенным вниз «усом».

Налепы представлены в виде вертикальных тройных параллельных полос, а также единичным налепом округлой формы.

Керамический материал, обнаруженный в погребальных комплексах, представлен слабопрофилированными горшками (рис. 3,4,6, $5,4)$ и единственным горшком баночного типа (рис. 3,8).

У всех сосудов дно плоское, в тесте примесь шамота, за исключением сосуда из погребения 1 кургана 2 - в нем примесь мелкого песка и белых частиц. Цвет поверхности сосудов варьирует от черного до кирпичнорозового.

Также в заполнении объектов кургана 2 были найдены фрагменты костей животных. Весь обнаруженный остеологический материал имеет поселенческий характер - по сохранности, степени раздробленности, по следам «кухонной разделки». Кости сильно раздроблены, на них фиксируются порубы, поломы, некоторые кости расколоты вдоль.

Большинство костей принадлежало млекопитающим. Из всех определимых костей подавляющее большинство - это кости домашних копытных животных. В остеологичес- ком спектре домашних животных преобладает лошадь - 53,8 \%, на втором месте крупный рогатый скот - 36,3\%, третью позицию занимает мелкий рогатый скот - 7,2 \%, и последнее место свинья - 2,7\%.

Что касается погребальных комплексов, то в погребении 4 было обнаружено 8 фрагментов от черепа и нижней челюсти мелкого рогатого скота. Возраст животного на момент забоя - 2-2,5 года.

Таким образом, исследованный памятник - курганная группа Панагия 2 - дал целый ряд комплексов, как погребальных, так и поселенческих, дополняющих и расширяющих наши представления о материальной культуре населения Таманского полуострова в древности, преимущественно в эпоху бронзы, памятники которой на Тамани до последнего времени были слабо изучены. Только в результате широкомасштабных исследований последних лет в зонах строительства был получен выразительный материал, относящийся к эпохе бронзы. Сейчас известно около двух десятков памятников этого периода [Кияшко, Сударев, 2018, c. 212]. Одним из них является поселение Панагия 1, комплексы которого были обнаружены в кургане 2. 


\section{ИЛЛЮСТРАЦИИ}
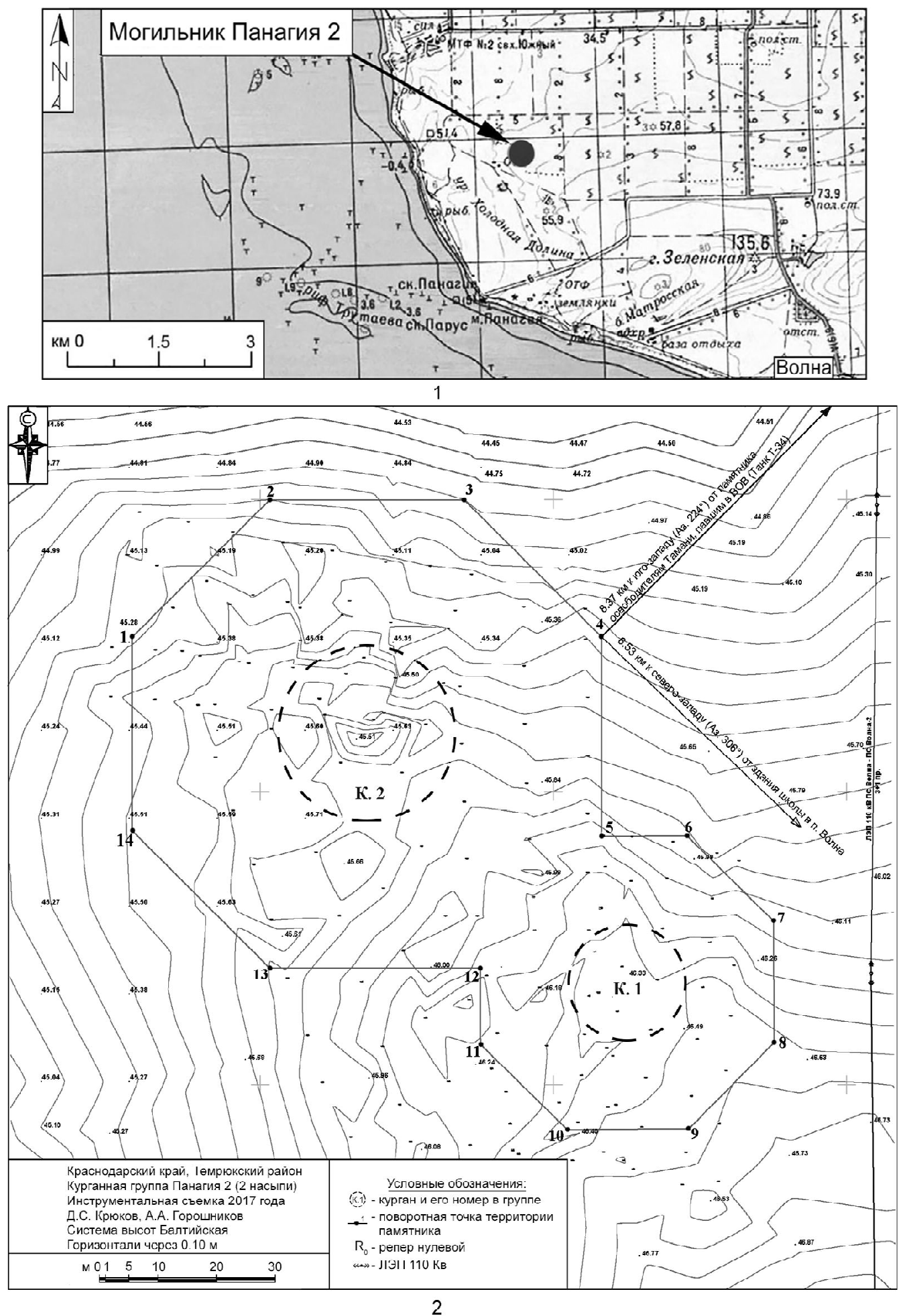

Рис. 1. Могильник Панагия 2:

1 - место расположения могильника Панагия 2 (выкопировка с карты М 1: 50 000); 2 - план курганного могильника Панагия 2 (М 1: 500)

Fig. 1. The burial mound Panagia 2:

1 - location at the map (scaling M 1: 50 000); 2 - plan (scaling M 1: 500) 
A.A. Goroshnikov. Studies of the Burial Mound Panagia 2 on the Taman Peninsula

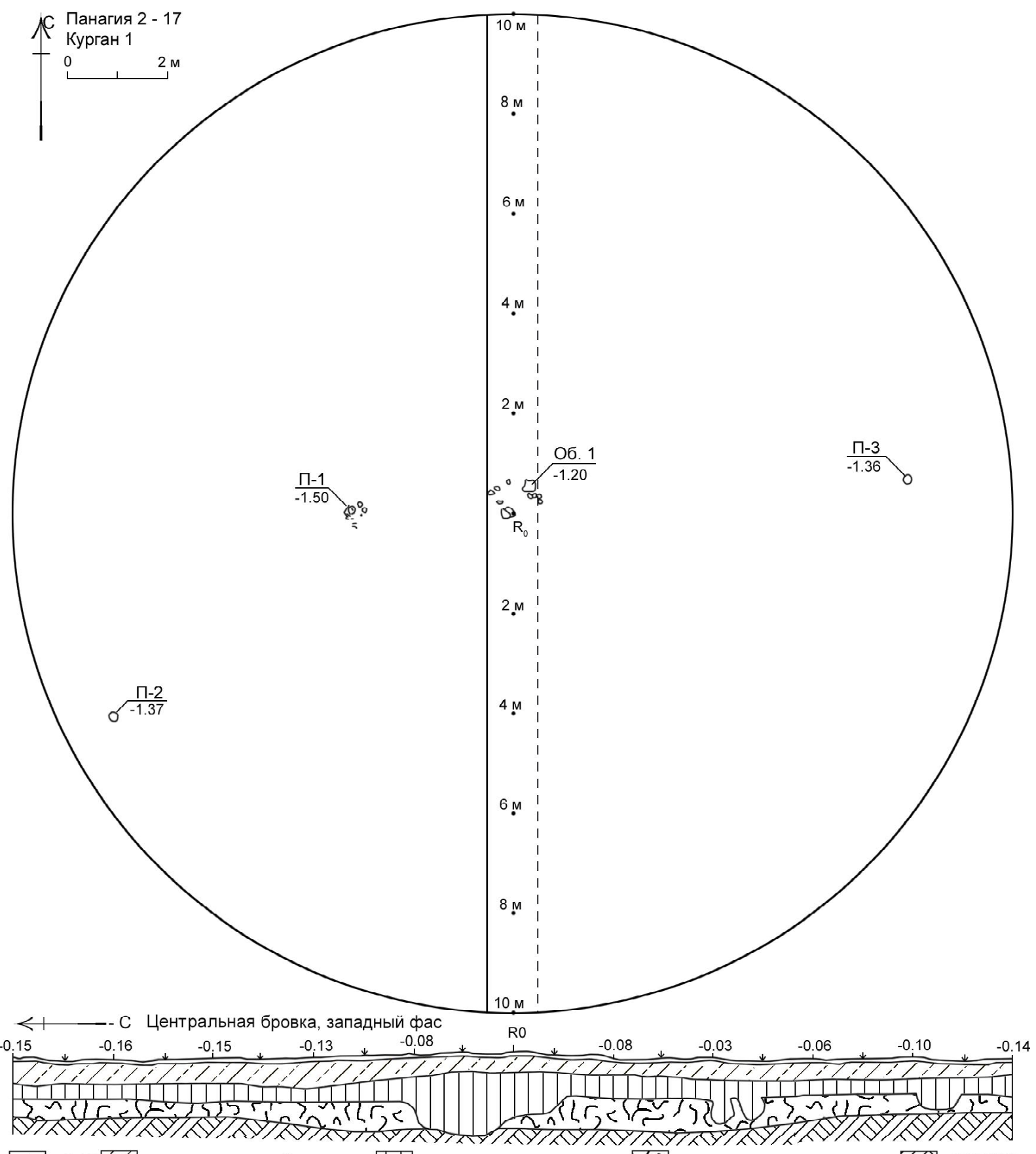

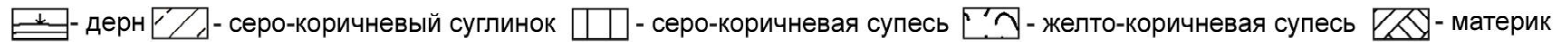

Рис. 2. Курган 1, общий план и профиль центральной бровки

Fig. 2. Barrow 1, plan and cross-section view 
А.А. Горошников. Исследования курганного могильника Панагия 2 на Таманском полуострове
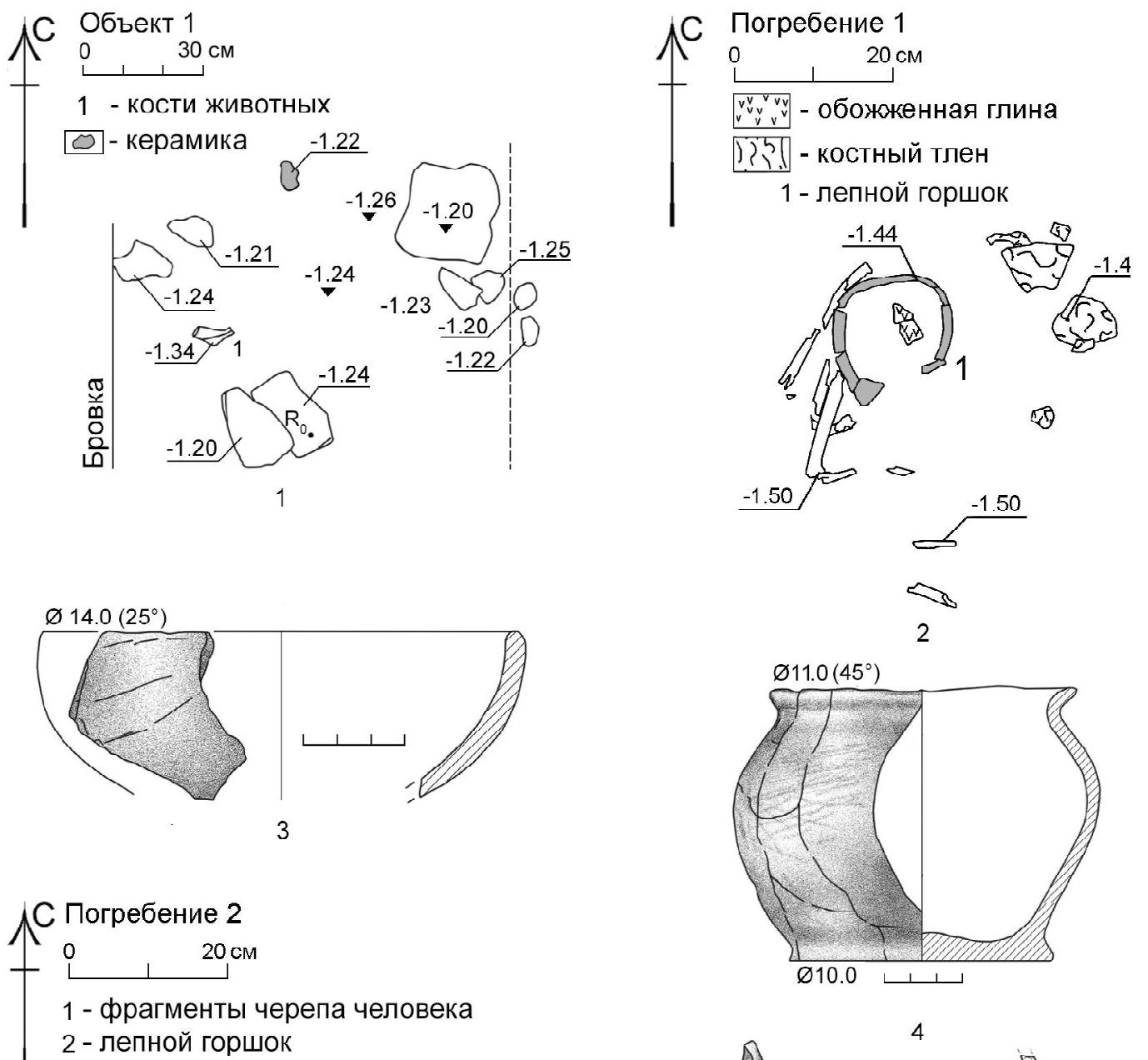

2 - лепной горшок
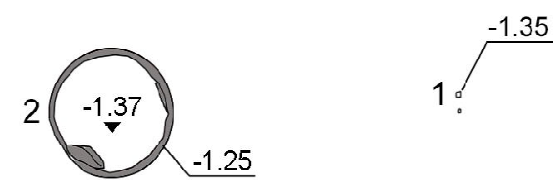

5
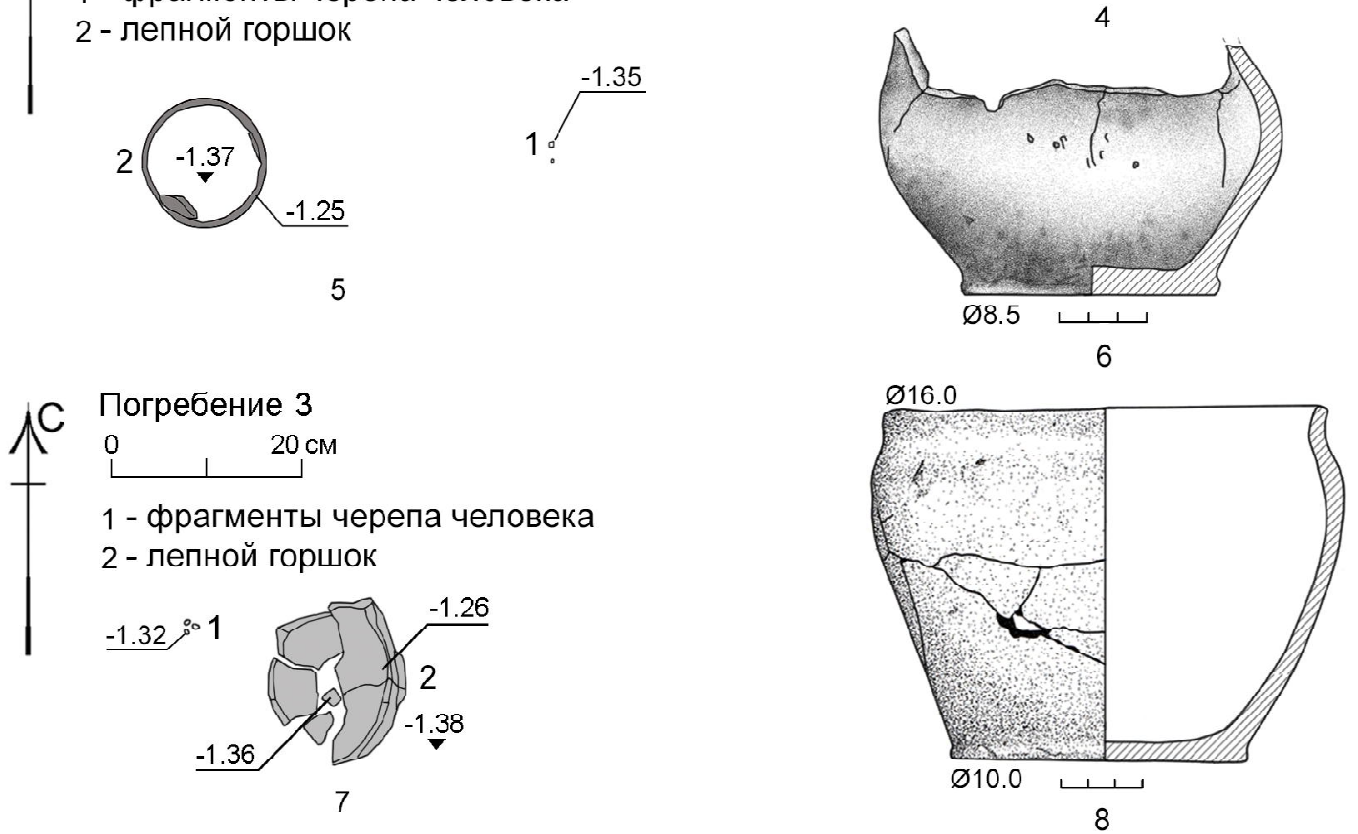

Рис. 3. Курган 1:

1 - объект 1, план; 2 - погребение 1, план; 3 - объект 1, находки; 4 - погребение 1, инвентарь;

5 - погребение 2, план; 6 - погребение 2, инвентарь; 7 - погребение 3 , план; 8 - погребение 3 , инвентарь

Fig. 3. Barrow 1:

1 - object 1 , plan; 2 - burial 1, plan; 3 - object 1 , finds; 4 - burial 1 , grave goods;

5 - burial 2, plan; 6 - burial 2, grave goods; 7 - burial 3, plan; 8 - burial 3, grave goods 

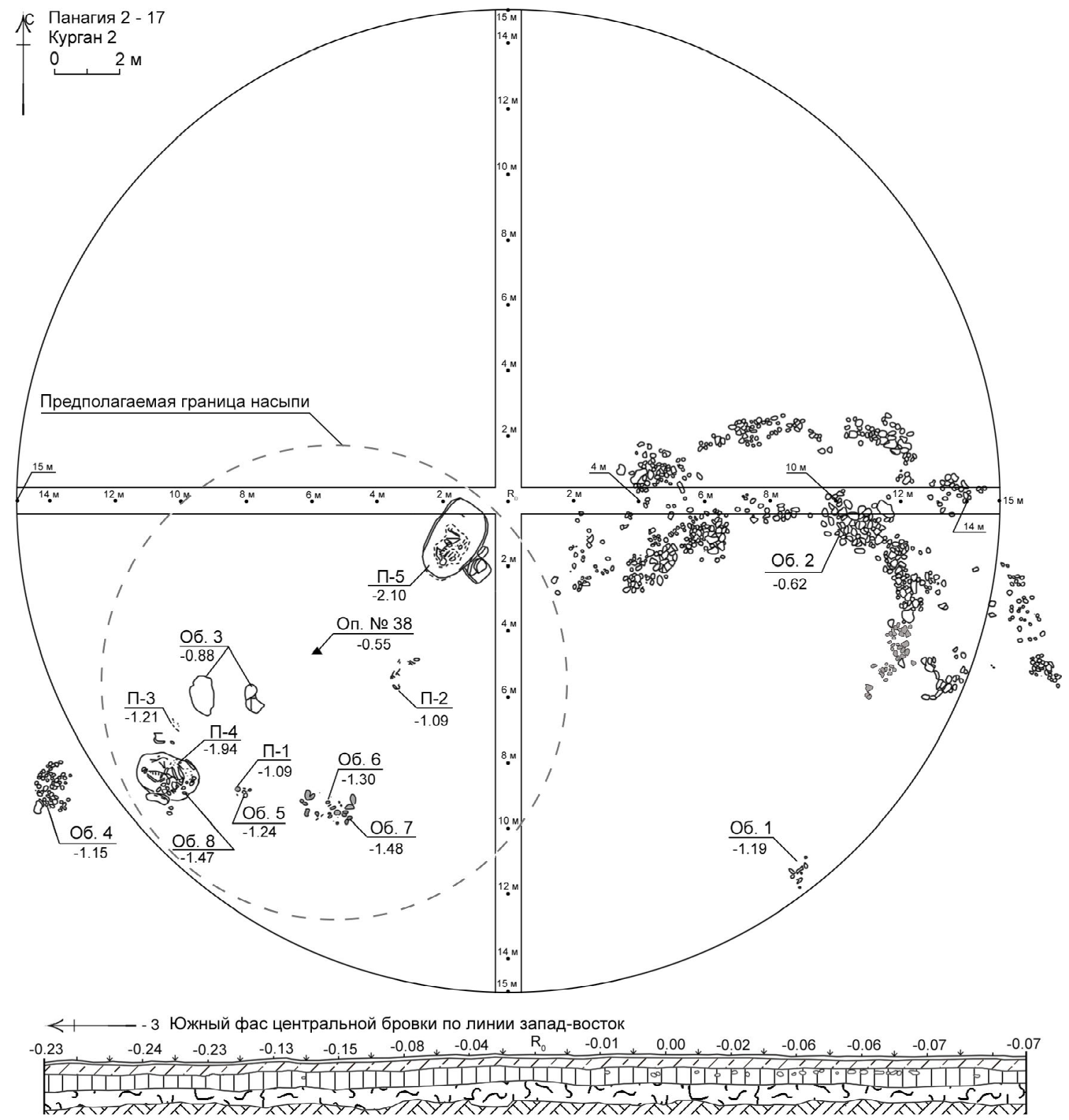

«- дерн

1

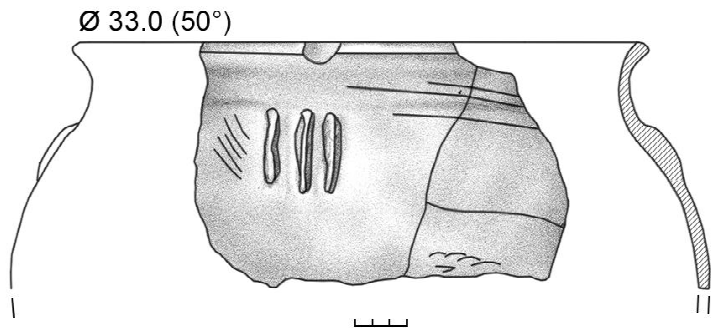

2

Рис. 4. Курган 2:

1 - общий план и профиль центральной бровки; 2 - находка в насыпи: фрагмент лепного сосуда

Fig. 4. Barrow 2:

1 - plan and cross-section view; 2 - find: fragment of a hand-made pot 
А.А. Горошников. Исследования курганного могильника Панагия 2 на Таманском полуострове

$$
\hat{f}^{\mathrm{c}}
$$$$
\begin{gathered}
\text { fC Погребение } 1 \\
1 \text { - лепной горшок } \\
2 \text { - фрагменты черепа } \\
\text { человека }
\end{gathered}
$$

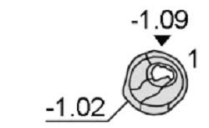

$$
-1.06 \rho_{0}^{2}
$$

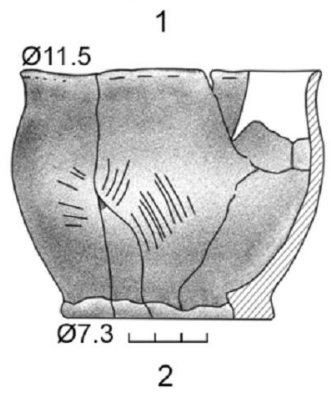

$+$

\section{огребение 4}

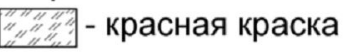

1 - кости животных

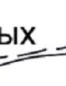
$-1.72 / 5$
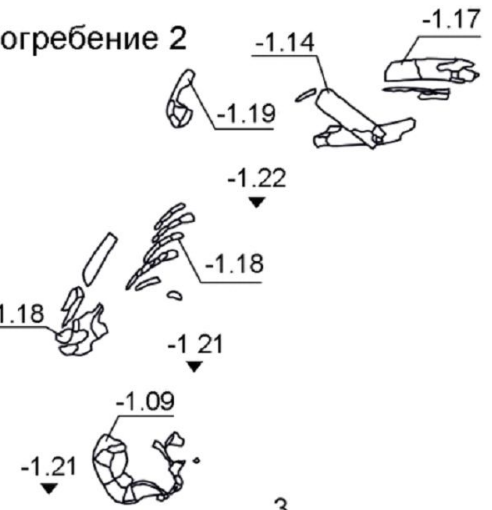

3
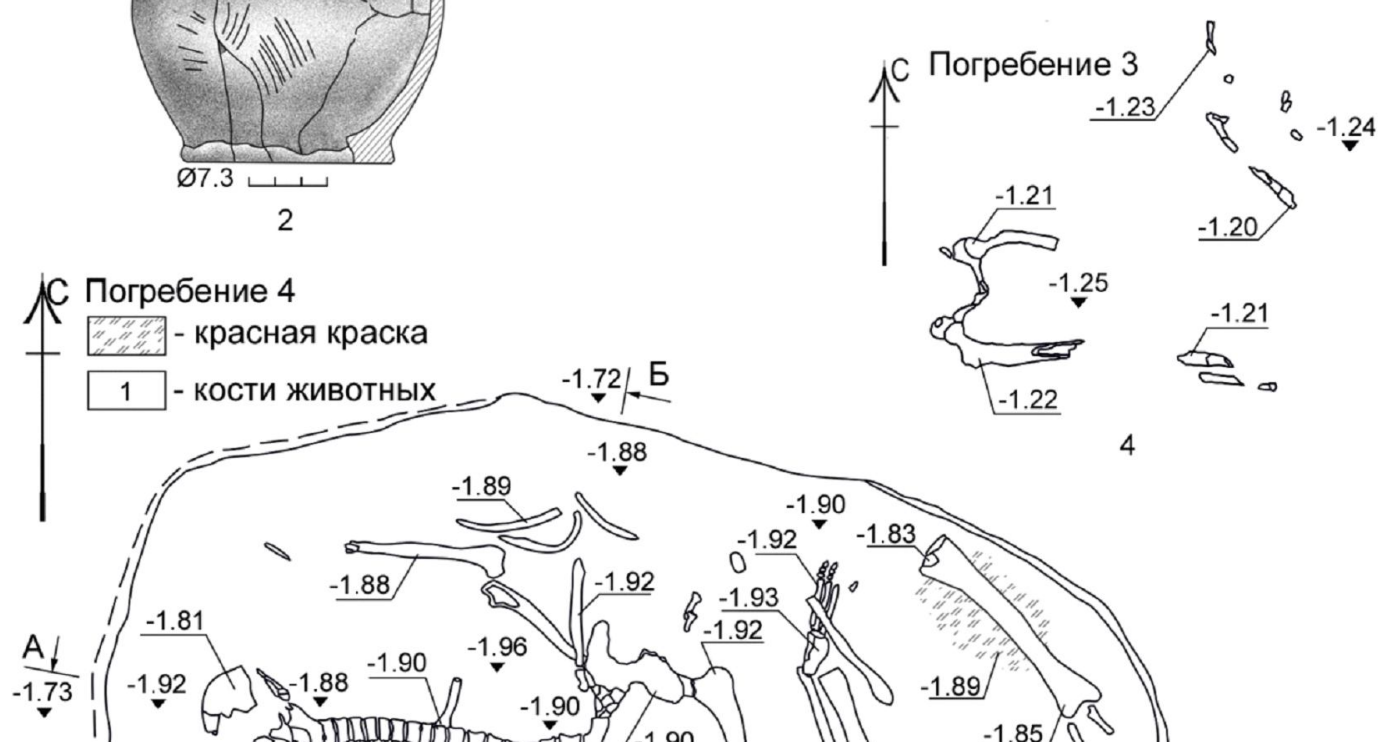

$0 \quad 30 \mathrm{~cm}$

для рисунков 1, 3-5

Рис. 5. Курган 2:

1 - погребение 1, план; 2 - погребение 1, инвентарь; 3 - погребение 2, план; 4 - погребение 3 , план; 5 - погребение 4 , план и разрезы

Fig. 5. Barrow 2:

1 - burial 1, plan; 2 - burial 1, grave goods; 3 - burial 2, plan; 4 - burial 3, plan; 5 - burial 4 , plan and cross-section views 


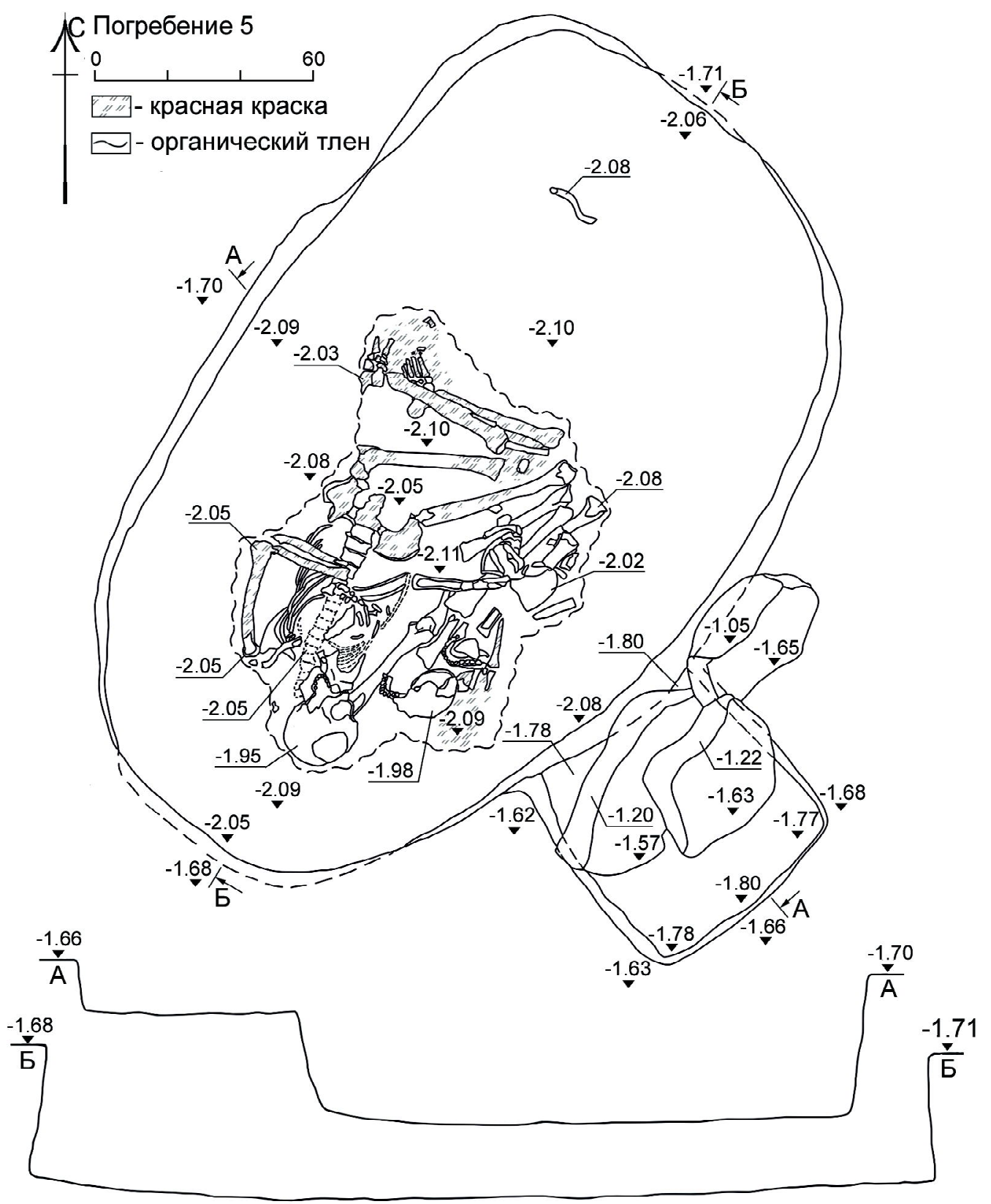

Рис. 6. Курган 2. Погребение 5, план и разрезы

Fig. 6. Barrow 2. Burial 5, plan and cross-section views 


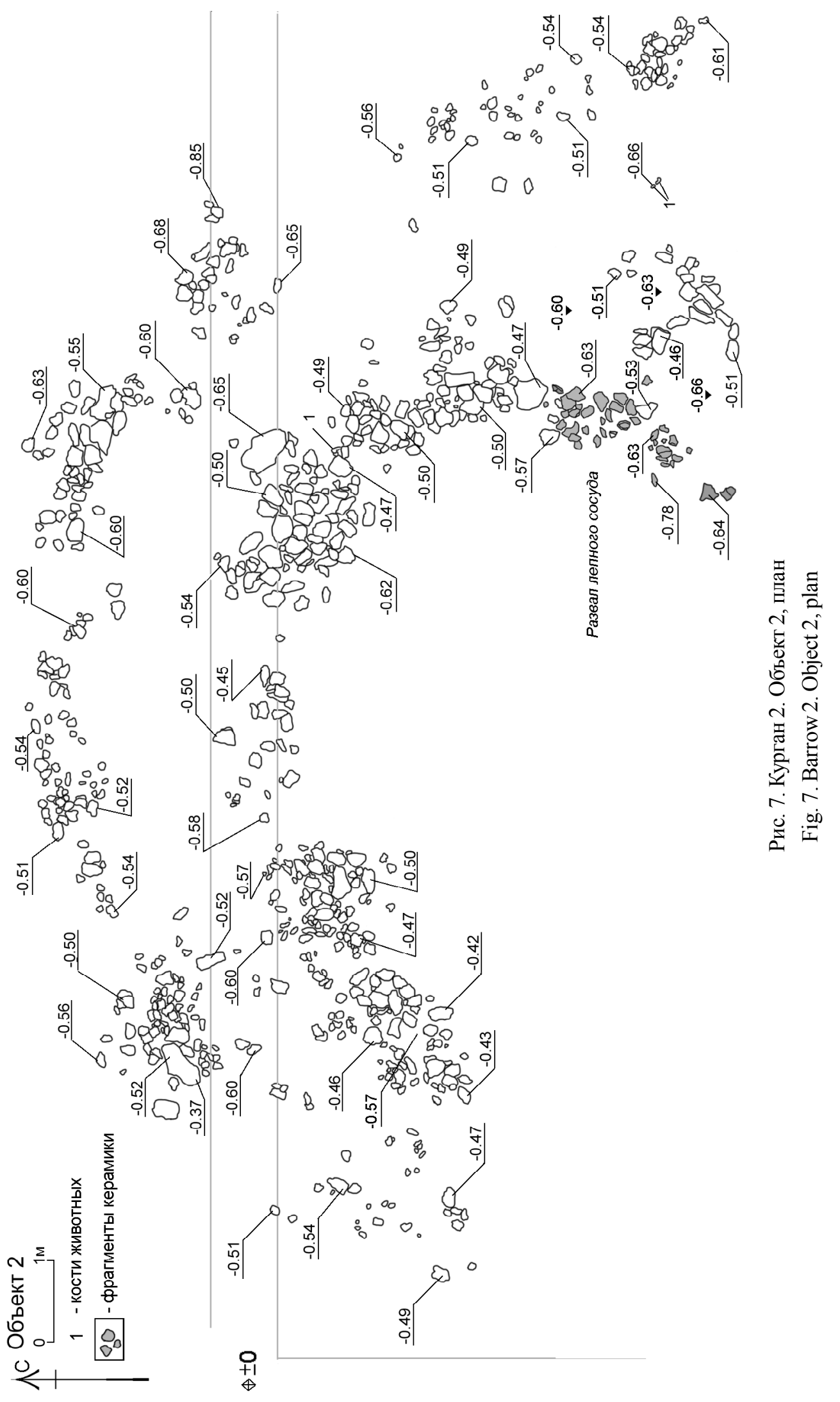


A.A. Goroshnikov. Studies of the Burial Mound Panagia 2 on the Taman Peninsula
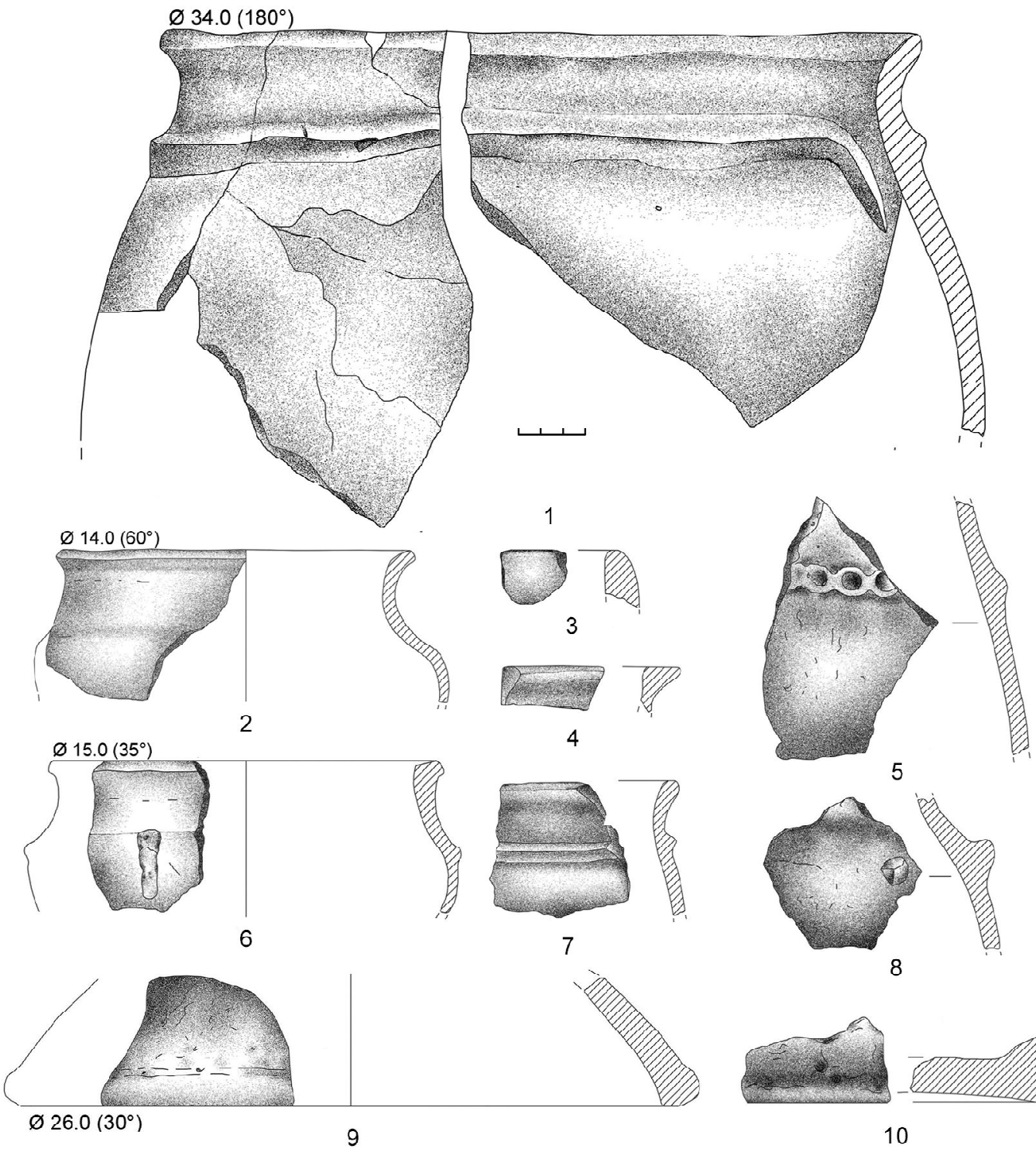

5
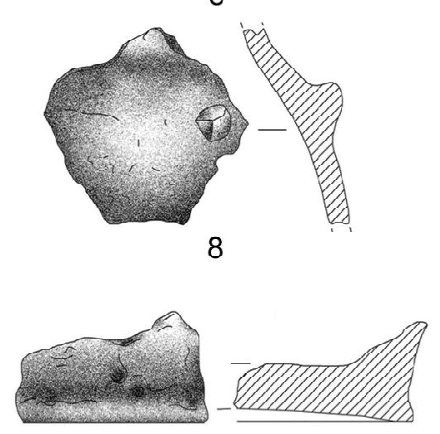

10
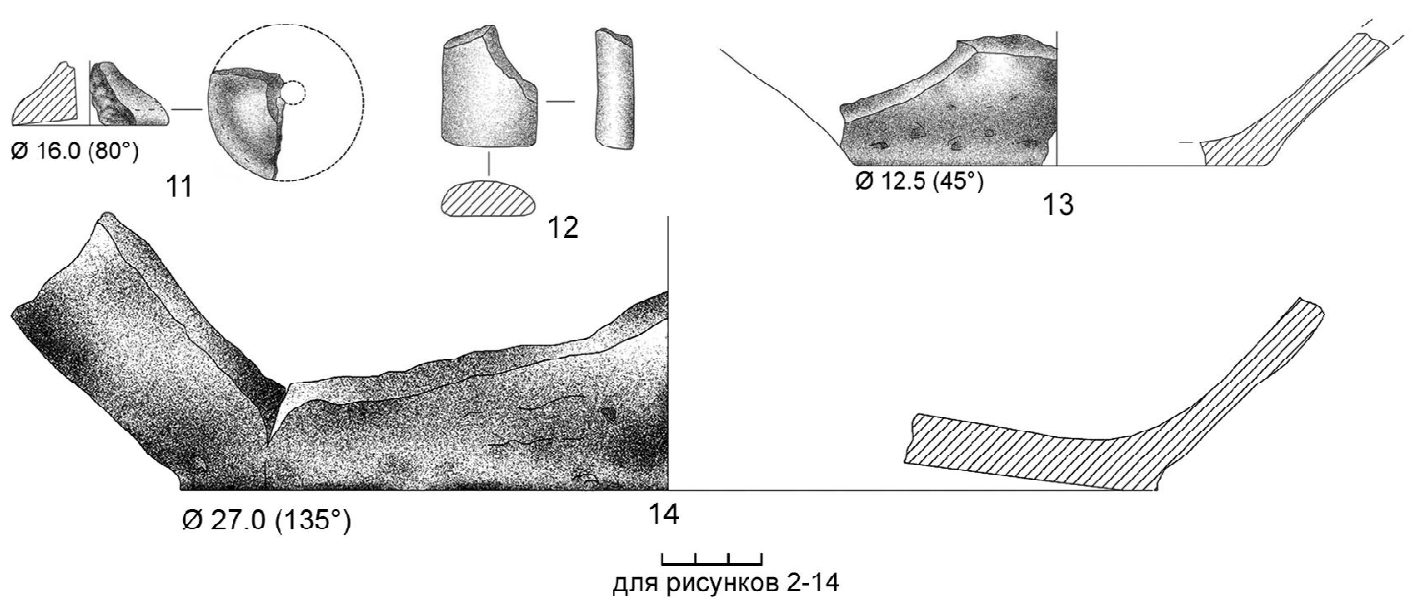

Рис. 8. Курган 2. Объект 2, находки:

1-10, 12-14 - профильные фрагменты лепных сосудов; 11 - фрагмент лепного пряслица

Fig. 8. Barrow 2. Object 2, finds:

$1-10,12-14$ - profile fragments of hand-made vessels; 11 - fragment of a spindle-whorl 
А.А. Горошников. Исследования курганного могильника Панагия 2 на Таманском полуострове
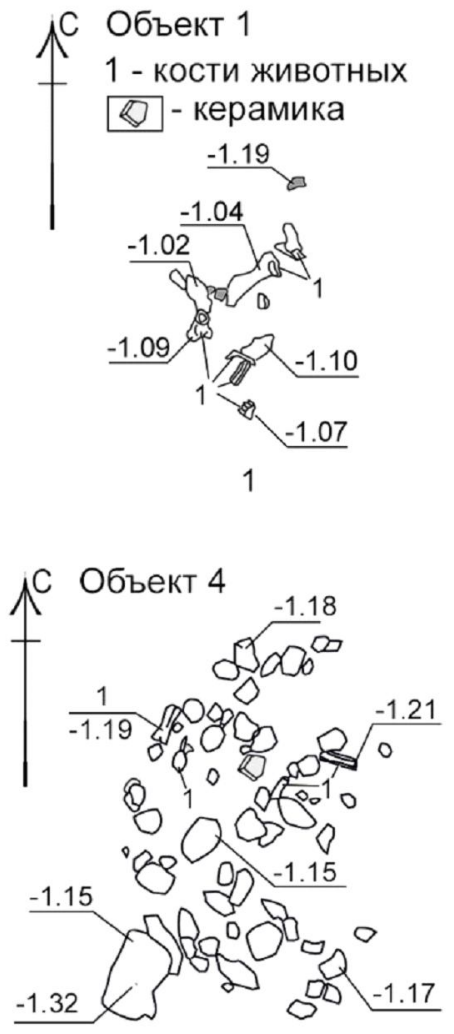

3

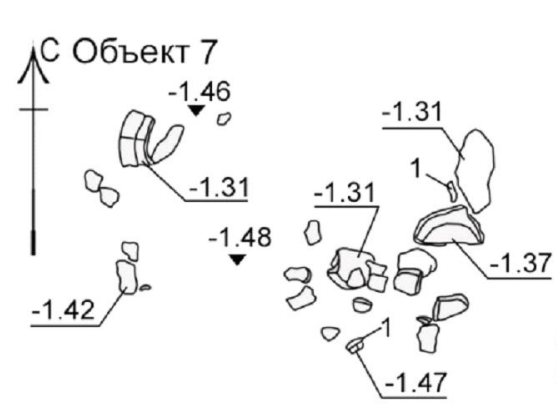

8

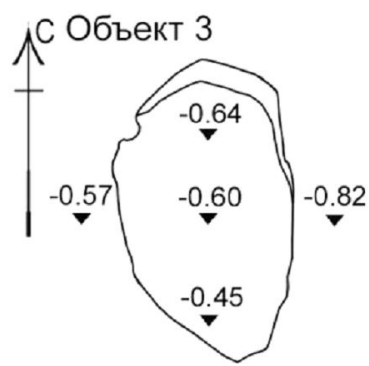

2

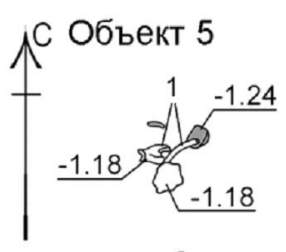

6

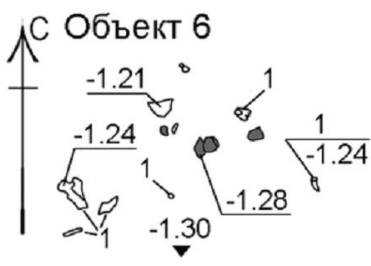

7

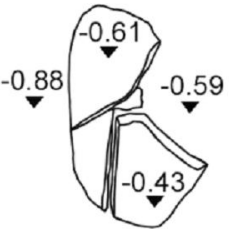

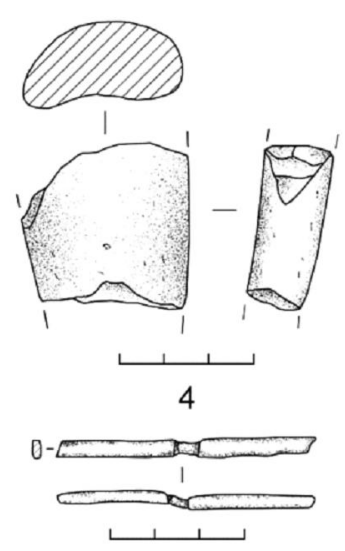

5

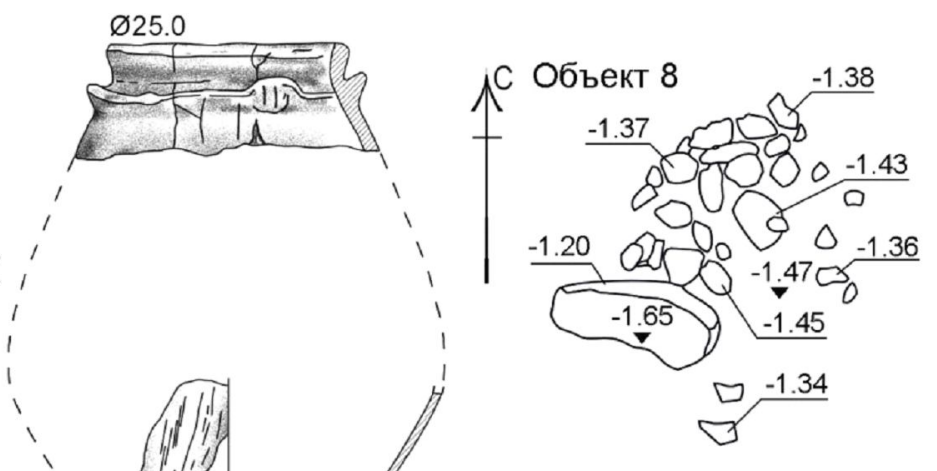

10

Рис. 9. Курган 2:

1 - объект 1, план; 2 - объект 3, план; 3 - объект 4, план; 4 - объект 4, находки: фрагмент ручки лепного сосуда; 5 - объект 4, находки: бронзовый стержень; 6 - объект 5, план; 7 - объект 6 , план; 8 - объект 7, план; 9 - объект 7, находки: фрагменты лепного горшка; 10 - объект 8 , план

Fig. 9. Barrow 2:

1 - object 1 , plan; 2 - object 3, plan; 3 - object 4 , plan; 4 - object 4 , finds: fragment of a hand-made vessel's handle; 5 - object 4 , finds: a bronze rod; 6 - object 5 , plan; 7 - object 6 , plan; 8 - object 7 , plan;

$9-$ object 7 , finds: fragments of the hand-made pot; $10-$ object 8 , plan 
A.A. Goroshnikov. Studies of Kurgan Burial Ground Panagia 2 on the Taman Peninsula

\section{ПРИМЕЧАНИЕ}

${ }^{1}$ Антропологические определения выполнены сотрудником КубГУ А.Н. Абрамовой.

\section{СПИСОК ЛИТЕРАТУРЫ}

Кияшко А. В., Сударев Н. И., 2018. К вопросу об этнокультурной принадлежности и хронологии памятников позднего бронзового века на Таманском полуострове // XIX Боспорские чтения. Боспор Киммерийский и варварский мир в период античности и средневековья. Традиции и инновации. Симферополь ; Керчь. С. 212-218.

Раев Б. А., Горошников А. А., 2018. Поселение Панагия 1 на Тамани (о связях Северного Кавказа и Карпато-Дунайского региона в предскифское время) // Народы и культуры Нижнего
Дуная в древности : материалы Междунар. науч.-практ. конф. Измаил. С. 135-142.

\section{REFERENCES}

Kiyashko A.V., Sudarev N.I., 2018. On the Issue of Ethnocultural Affiliation and Chronology of the Monuments of the Late Bronze Age on the Taman Peninsula. XIX Bosporan Readings. Cimmerian Bosporus and the World of Barbarians in Antiquity and the Middle Ages. Traditions and innovations. Simferopol; Kerch, pp. 212-218. (in Russian).

Raev B.A., Goroshnikov A.A., 2018. The Settlement of Panagia 1 on Taman (on the Relations between the North Caucasus and the Carpatho-Danube Region in the Pre-Scythian Time). Narody i kultury Nizhnego Dunaya $v$ drevnosti: materialy Mezhdunar. nauch.-prakt. konf. Izmail, pp. 135-142.

\section{Information about the Author}

Andrey A. Goroshnikov, Senior Researcher, Kubanarkheologiya Ltd., Kubanskaya Emb., 37/11, 350063 Krasnodar, Russian Federation, goroshnikov89@bk.ru.

\section{Информация об авторе}

Андрей Алексеевич Горошников, старший научный сотрудник, ООО «Кубаньархеология», Кубанская Набережная, 37/11, 350063 г. Краснодар, Российская Федерация, goroshnikov89@bk.ru. 